\title{
Limb length in bariatric surgery of Roux-en-Y gastric bypass (RYGB): An integrative review
}

\author{
Longitud del asa intestinal en la cirugía bariátrica de bypass gástrico en \\ Y de Roux (BGYR): Una revisión integradora \\ Bruno Landal Cavassin', Carolina Cabral Brandalizze ${ }^{1}$
}

\begin{abstract}
Introduction: Roux-en-Y gastric bypass is considered the gold standard surgical technique for obesity. The variation in limb length may be related to metabolic improvement and nutritional deficiencies. However, the ideal measurement still a controversial subject in the literature. This study aims to perform an integrative literature review and associate the optimal limb length, considering the maximum weight loss with the minimum nutritional complications. Methods: Integrative literature review conducted using electronic searches (1992 - 2020) in databases MEDLINE/Pubmed and BVS (Biblioteca Virtual da Saúde)/LILACS, through the terms "(bariatric surgery) AND (limb length)". A total of 340 articles were found, 26 articles were included in this review. Results: Current evidence supports using shorter limb lengths in patients with $\mathrm{BMI}<50 \mathrm{~kg} / \mathrm{m}^{2}$, and longer limbs in patients with severe type 2 diabetes mellitus and/or dyslipidemia or superobese patients $\left(\mathrm{BMI}>=50 \mathrm{~kg} / \mathrm{m}^{2}\right.$ ), considering the benefits in comorbidities resolution. A shorter common limb increases the incidence of nutritional disorders. There is a wide variation in jejunoileal length among patients. Conclusion: Measuring the intraoperative jejunoileal length and individualizing the surgery may bring benefits in weight loss, comorbidities resolution, and reduce the incidence of nutritional disorders. However, more randomized controlled trials are needed on this topic.
\end{abstract}

Keywords: bariatric surgery; gastric bypass; obesity; morbid obesity; obesity management; small intestine.

\section{Resumen}

Introducción: el bypass gástrico en Y de Roux se considera la técnica quirúrgica estándar de oro para la obesidad. La variación en la longitud del asa intestinal puede estar relacionada con la mejora metabólica y las deficiencias nutricionales, sin embargo, la longitud ideal sigue siendo un tema controvertido en la literatura. El objetivo de este estudio es realizar una revisión integradora de la literatura y asociar la longitud ideal del asa intestinal, considerando la máxima pérdida de peso con las mínimas complicaciones nutricionales. Materiales y Métodos: revisión bibliográfica integradora realizada mediante búsquedas electrónicas (1992 - 2020) en bases de datos MEDLINE/Pubmed y BVS (Biblioteca Virtual da Saúde) / LILACS, a través de los términos "(bariatric surgery) AND (limb length)". Se encontraron un total de 340 artículos, 26 artículos fueron incluidos en esta revisión. Resultados: la evidencia actual respalda el uso de asas intestinales más cortas en pacientes con IMC $<50 \mathrm{~kg} / \mathrm{m}^{2}$ y asas intestinales más largas en pacientes con diabetes mellitus tipo 2 grave y/o dislipidemia o pacientes superobesos (IMC $>=50 \mathrm{~kg} / \mathrm{m}^{2}$ ), considerando los beneficios en la resolución de comorbilidades. La asa común más corto aumenta la incidencia de trastornos nutricionales. Existe una amplia variación en la longitud yeyunoileal entre los pacientes. Conclusiones: la medición de la longitud yeyunoileal intraoperatoria y la individualización de la cirugía pueden traer beneficios en la pérdida de peso, la resolución de comorbilidades y reducir la incidencia de trastornos nutricionales. Sin embargo, se necesitan más ensayos controlados aleatorios sobre este tema.

Palabras clave: cirugía bariátrica; derivación gástrica; obesidad; obesidad mórbida; manejo de la obesidad; intestino delgado.

Date of submission: 2021-01-19 - Date of approval: 2021-06-16

(1) School of Medicine, Pontifical Catholic University of Paraná, Curitiba, PR, Brazil

Corresponding author: brunocavassin@gmail.com 


\section{Introduction}

Obesity represents a substantial part of the global health problem. Defined as excess body fat and body mass index (BMI) above 30 $\mathrm{kg} / \mathrm{m}^{2}$, this disease is associated with an increased risk of type 2 diabetes mellitus (DM2), systemic arterial hypertension, coronary disease, cerebrovascular disease, and different types of cancers (Engin, 2017).

The main points of obesity treatment are lifestyle change (LSC) and/ or pharmacological treatment and/or surgical treatment. Currently, the world performs more than 800 thousand bariatric surgeries per year, which is considered, in association with LSC, the most effective long-term technique for treating this disease. Vertical gastrectomy (sleeve) is the most performed bariatric surgery in the world, with 47\%. Roux-en-Y gastric bypass (RYGB) has second place, with 35,3\% (Ramos et al., 2019).

RYGB, considered the gold standard surgery by many authors, leads to an excess weight loss (\%EWL) between $60-80 \%$ and consists of creating a small gastric pouch associated with intestinal bypass. This method combines the restrictive with the malabsorptive technique. The intestinal bypass is characterized by the creation of 3 limbs: alimentary limb (AL), biliopancreatic limb (BL), and common limb (CL) (Figure 1). RYGB is associated with significant metabolic improvements and often a reversal of arterial hypertension, DM2, dyslipidemia, and sleep apnea (Ramos et al., 2019). However, it can be associated with nutritional deficiencies, such as proteins, iron, zinc, and vitamins B12 and D (Sampaio-Neto et al., 2016).

The variation in limb length may be related to metabolic improvement and possible nutritional deficiencies. Therefore, the ideal measurement is still a subject to be clarified in the literature (Ahmed et al., 2019).

Through an integrative literature review, this study main aim is to evaluate the limb length in Roux-en- $Y$ gastric bypass and the association with the BMI and comorbidities in the pre-operatory period, as well as considering the ideal limb length to generate a better postoperative outcome, contemplating the maximum weight loss with the minimum possible nutritional disorders.

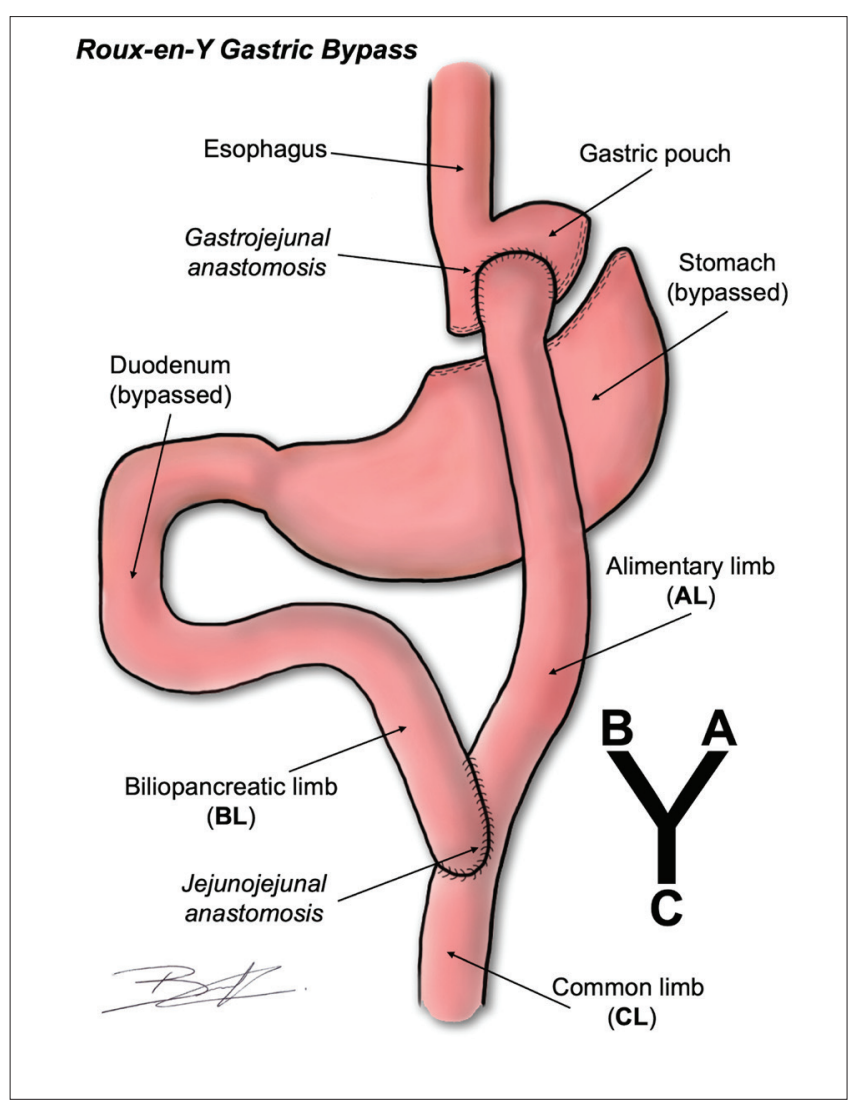

Figure 1: Schematic figure of the surgical aspect of RYGB (Author: Cavassin, BL).

\section{Methods}

We performed an integrative literature review using electronic searches (1992-2021), which used the terms "(bariatric surgery) AND (limb length)" in the MEDLINE/Pubmed and BVS (Biblioteca Virtual da Saúde)/LILACS databases. In addition to the articles found in the databases, some studies in the references of the analyzed articles were included.

The selection criteria included articles published in English, Portuguese and Spanish, that were chosen according to the fulfillment of the previously established selection criteria that correspond to: (1) adults over 18 years old undergoing RYGB bariatric surgeries. (2) RYGB bariatric surgeries correlate the jejunoileal length and/or the alimentary limb and/or biliopancreatic limb and/or common limb. (3) Outcomes associated with weight loss and/or nutritional deficiencies during the postoperative period. Articles that did not correlate the limb length, studies performed on animals, and case reports were excluded. 
Two researchers recorded the information from each study separately upon assessment of the risk of bias and results. When discrepancies occurred, the final decision was made by consensus. A total of 340 articles were found, 96 were duplicates, and 176 articles were excluded. Sixty-eight papers were read in full. Twenty-six articles were selected to compose this integrative review of the literature (Figure 2).

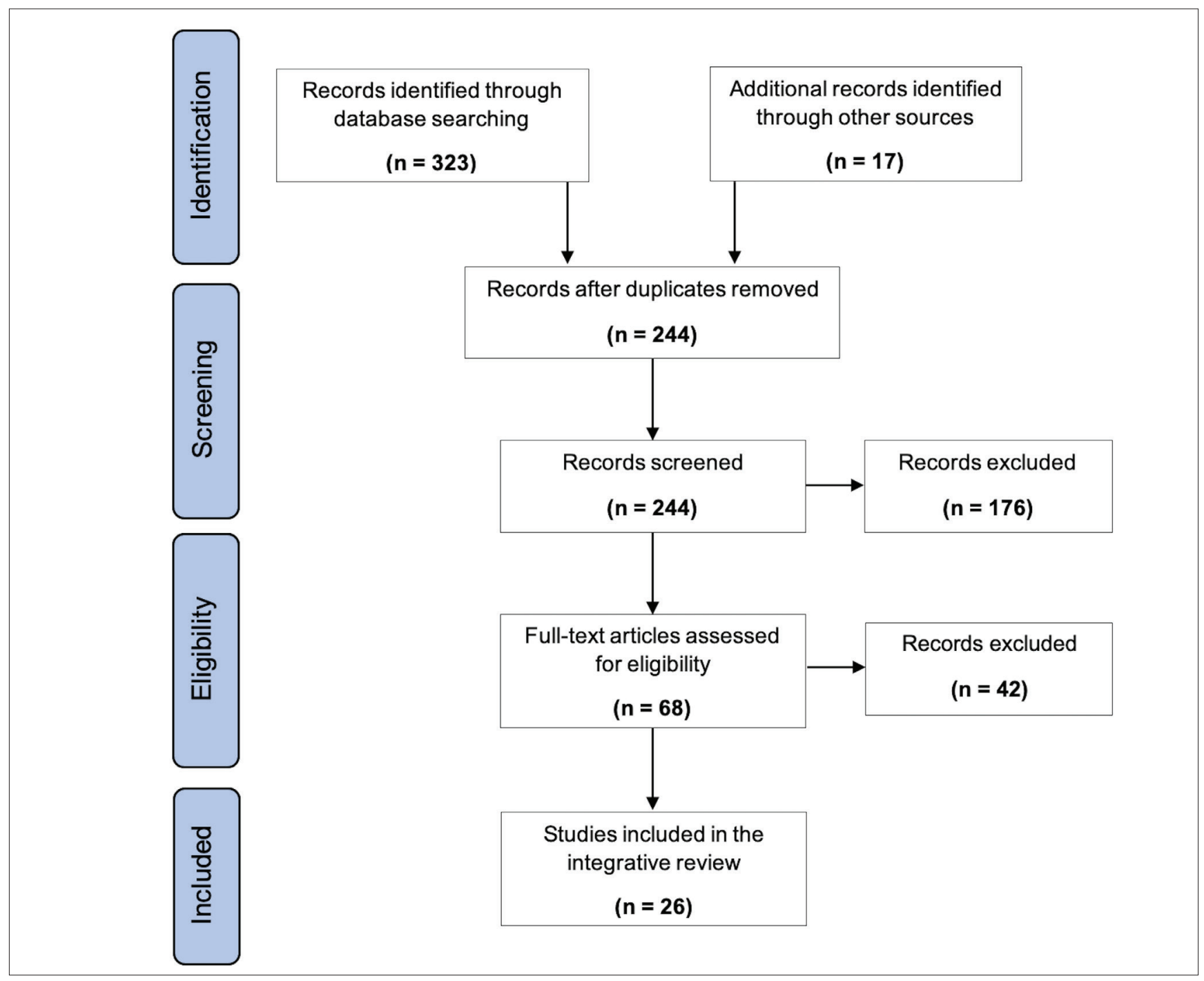

Figure 2: Studies selection flowchart

\section{Results}

\section{A longer alimentary limb is beneficial in superobese}

Brolin et al. (1992) published the first randomized study that studied the variation of limb length in superobese patients, defined as BMI >=50 kg/m². Greater \%EWL was reported in the group with longer limbs ( $A L 150 \mathrm{~cm}, B L 30 \mathrm{~cm}(A L+B L=180$ $\mathrm{cm})$ ), without significant vitamin deficiencies and/or diarrhea after three years. (Ciovica et al., 2008); Gleysteen, 2009 in a prospective and retrospective study, respectively, also obtained a greater \%EWL with longer AL in superobese patients.

Gan et al. (2018), after a systematic review of the literature and meta-analysis with 1714 patients, recommend an AL 130-150 cm for superobese patients and $\mathrm{AL} 40-100 \mathrm{~cm}$ for non-superobese patients. Stefanidis et al. (2011), in another systematic review, also considered that patients with a $\mathrm{BMI}>=50 \mathrm{~kg} / \mathrm{m}^{2}$ should receive an $\mathrm{AL}>=150 \mathrm{~cm}$. 


\section{Different lengths are associated with metabolic improvement}

Kaska et al. (2014) concluded that the differences in measures did not influence weight loss, but there were more cases of DM2 remissions in patients with $\mathrm{AL}$ close to $150 \mathrm{~cm}$ and $\mathrm{BL} 100-150$ $\mathrm{cm}$. These authors also recommend $\mathrm{CL}>150 \mathrm{~cm}$.

Pinheiro et al. (2008) reported that superobese patients with AL 250 $\mathrm{cm}, \mathrm{BL} 100 \mathrm{~cm}(\mathrm{AL}+\mathrm{BL}=350 \mathrm{~cm})$ had better control of DM2 $(\mathrm{p}<0.05)$ and dyslipidemia $(p<0.05)$, if compared with patients of $A L 150 \mathrm{~cm}, B L$ $50 \mathrm{~cm}(\mathrm{AL}+\mathrm{BL}=200 \mathrm{~cm})$, without major nutritional differences. The authors cite that one of the possible causes for the improvement of $\mathrm{DM} 2$ and dyslipidemia is the longer length of the $\mathrm{BL}$, characterizing a lesser circulation of free fatty acids in the portal circulation.

Nora et al. (2017) studied patients with $\mathrm{BMI}<50 \mathrm{~kg} / \mathrm{m}^{2}$ and concluded that $A L 120 \mathrm{~cm}$ and $B L 200 \mathrm{~cm}(A L+B L=320 \mathrm{~cm})$ are superior in $\mathrm{DM} 2$ remission and \%EWL compared to $\mathrm{AL} 120 \mathrm{~cm}$ and $\mathrm{BL} 84+/-2$ $\mathrm{cm}(\mathrm{AL}+\mathrm{BL} \sim 200 \mathrm{~cm})$, without major nutritional complications between groups after 5 years.

Homan et al. (2018) in a randomized controlled study, concluded that $\mathrm{AL} 75 \mathrm{~cm}, \mathrm{BL} 150 \mathrm{~cm}(\mathrm{AL}+\mathrm{BL}=225 \mathrm{~cm})$ had a higher \%EWL $(p=0.049)$ and more remission of dyslipidemia $(p=0.022)$, if compared to $A L 150 \mathrm{~cm}, \mathrm{BL} 75 \mathrm{~cm}$. DM2 remission, arterial hypertension, and nutritional complications were similar between the two groups after four years.

\section{Different lengths are not associated with weight loss}

Choban \& Flancbaum (2002) compared the influence of the alimentary limb on non-superobese and superobese patients. After three years, the authors concluded that there was no significant benefit from longer limbs. In patients with CL $250 \mathrm{~cm}$, no case of protein-calorie malnutrition or calcium deficiency was noted.

Christou et al. (2006) compared non-superobese and superobese after ten years of follow-up. Similar weight loss has been reported between $A L 40 \mathrm{~cm}, B L 10 \mathrm{~cm}(A L+B L=50 \mathrm{~cm})$ and $A L 100 \mathrm{~cm}, B L$ $100 \mathrm{~cm}(\mathrm{AL}+\mathrm{BL}=200 \mathrm{~cm})$.

Valezi et al. (2014) randomized 120 patients (mean BMI $46 \mathrm{~kg} / \mathrm{m}^{2}$ ) in 4 groups with $\mathrm{AL}+\mathrm{BL}$ ranging from 150 to $250 \mathrm{~cm}$. No relationship was found between limb length and weight loss after one year postoperatively. In studies with similar AL + BL, (Inabnet et al.,2005; Ramos et al., 2016) also found no significant difference in weight reduction after two years.

Sarhan et al. (2011) concluded that there was no difference in \%EWL and complications between AL 170-200 cm compared to AL 120-150 $\mathrm{cm}$ in superobese patients for three years (BL 50-80 cm in both groups).

\section{Longer bypass can lead to worsening quality of life and/or more significant nutritional deficiency}

Risstad et al. (2016) carried out a double-blind, randomized study with only superobese patients. Patients with CL $150 \mathrm{~cm}$ had more diarrhea, secondary hyperparathyroidism, and lower albumin levels, with similar \%EWL ( $p=0.032$ ). Nergård et al. (2020), in another randomized study, also concluded that patients with CL 150 $\mathrm{cm}$ had a higher incidence of diarrhea $(p=0.006)$, without higher $\% \operatorname{EWL}(p=0.085)$, even after five years.

Ruiz-Tovar et al. (2019) studied 506 patients in a prospective randomized study. Group 1 (BMI $44.2+/-5.2$ kg/m²): BL $70 \mathrm{~cm}$ $(\mathrm{AL}+\mathrm{BL}=220 \mathrm{~cm})$ vs. Group $2\left(\mathrm{BMl} 44.1+/-4.1 \mathrm{~kg} / \mathrm{m}^{2}\right): \mathrm{BL} 120$ $\mathrm{cm}(A L+B L=270 \mathrm{~cm})$. The authors concluded no difference between the groups for weight loss, DM2 remission, dyslipidemia, and hypertension. However, the group with longer limbs was associated with a greater deficiency of vitamin B12, vitamin A, and folic acid over five years.

(Savassi-Rocha et al., 2008; Tacchino, 2015) suggest measuring jejunoileal length to avoid more significant nutritional deficiencies. Like Chen et al. (2019), as they concluded that $C L<400 \mathrm{~cm}$ was related to a greater protein deficiency. Ghiassi et al. (2018) concluded that diarrhea and malabsorption usually occur when the patient has an $A L+C L<250-300 \mathrm{~cm}$, but with improvement after reparative surgery for $A L+C L$ of $400-450 \mathrm{~cm}$.

Nergaard et al. (2014), in a randomized study, mentioned that AL $60 \mathrm{~cm}, B L 200 \mathrm{~cm}(A L+B L=260 \mathrm{~cm})$ despite being superior in weight loss compared to $A L 150 \mathrm{~cm}, B L 60 \mathrm{~cm}(A L+B L=210 \mathrm{~cm})$, are associated with greater iron and vitamin $D$ deficiency, as well as diarrhea and similar resolution of DM2, arterial hypertension and sleep apnea in both non-superobese and superobese after seven years. According to a systematic review (Mahawar et al. 2016), the best results occur when $A L+B L=100-200 \mathrm{~cm}$. They mention that $A L$ $+\mathrm{BL}>200 \mathrm{~cm}$ can be considered in superobese patients, however $\mathrm{CL}<100 \mathrm{~cm}$ can causes nutritional complications. Sugerman et al. (1997) said that a CL $50 \mathrm{~cm}$ is unacceptable due to postoperative nutritional deficiency, and a CL $150 \mathrm{~cm}$ can be used for superobese patients with severe comorbidities. However, it is preferable to use a CL > 200-250 cm.

Gadiot et al. (2020) reported a higher rate of laparoscopic reintervention and greater calcium, iron, and vitamin $\mathrm{D}$ deficiencies in the group with variable $A L$ and $C L 100 \mathrm{~cm}$. They did not find significant differences in weight loss, resolution of DM2, dyslipidemia after one year.

All main points results are summarized in Table 1. 
Landal \& Cabral.

Table 1: Articles main points according to the citation order in the text

\begin{tabular}{|c|c|c|c|c|c|}
\hline Study & Type & $\mathbf{n}$ & BMI & Lengths with better outcome & Comments \\
\hline Brolin et al., 1992 & $\mathrm{RCT}$ & 45 & so & $\mathrm{AL} 150 \mathrm{~cm}, \mathrm{BL} 30 \mathrm{~cm}$ & Greater \%EWL, without major ND and/or diarrhea. \\
\hline Ciovica et al., 2008 & Prosp & 137 & so & $\mathrm{AL} 150 \mathrm{~cm}, \mathrm{BL} 30 \mathrm{~cm}$ & Greater \%EWL. \\
\hline Gleysteen, 2009 & Retro & 344 & NSO, SO & $\mathrm{AL}>130 \mathrm{~cm}, \mathrm{BL} 18-30 \mathrm{~cm}$ & Greater \%EWL in superobese patients. \\
\hline Gan et al., 2018 & MA & 1714 & so & AL $130-150 \mathrm{~cm}$ & $\begin{array}{l}\text { More weight loss. Recommend AL } 40-100 \mathrm{~cm} \text { for NSO } \\
\text { patients. }\end{array}$ \\
\hline Stefanidis et al., 2011 & SR & 1426 & so & $\mathrm{AL}>=150 \mathrm{~cm}$ & More weight loss. \\
\hline Kaska et al., 2014 & Prosp & 93 & NSO, SO & AL $150 \mathrm{~cm}, \mathrm{BL} 100-150 \mathrm{~cm}$ & Better DM2 resolution. Support $\mathrm{CL}>150 \mathrm{~cm}$ to avoid ND \\
\hline Pinheiro et al., 2008 & $\mathrm{RCT}$ & 105 & so & $\mathrm{AL} 250 \mathrm{~cm}, \mathrm{BL} 100 \mathrm{~cm}$ & Better DM2 and dyslipidemia resolution, without major ND \\
\hline Nora et al., 2017 & Prosp & 114 & NSO & $A L 120 \mathrm{~cm}, \mathrm{BL} 200 \mathrm{~cm}$ & Better DM2 control and greater \%EWL, without major ND \\
\hline Homan et al., 2018 & $\mathrm{RCT}$ & 146 & NSO & $\mathrm{AL} 75 \mathrm{~cm}, \mathrm{BL} 150 \mathrm{~cm}$ & Better dyslipidemia control. \\
\hline Choban \& Flancbaum, 2002 & $\mathrm{RCT}$ & 133 & NSO, SO & $\mathrm{AL} 75-150 \mathrm{~cm}, \mathrm{BL} 30 \mathrm{~cm}$ & Support longer AL only in SO patients. \\
\hline Christou et al., 2006 & Retro & 228 & NSO, SO & $\mathrm{AL} 40 \mathrm{~cm}, \mathrm{BL} 10 \mathrm{~cm}$ & Longer limbs was not associated with greater \%EWL. \\
\hline Valezi et al., 2014 & $\mathrm{RCT}$ & 120 & NSO & $\mathrm{AL} 100 \mathrm{~cm}, \mathrm{BL} 50 \mathrm{~cm}$ & Longer limbs was not associated with greater \%EWL. \\
\hline Inabnet et al., 2005 & RCT & 48 & NSO & $A L 100 \mathrm{~cm}, \mathrm{BL} 50 \mathrm{~cm}$ & Longer limbs was not associated with greater \%EWL. \\
\hline Ramos et al., 2016 & Retro & 63 & NSO, SO & $\mathrm{AL} 100 \mathrm{~cm}, \mathrm{BL} 50 \mathrm{~cm}$ & Longer limbs was not associated with greater \%EWL. \\
\hline Sarhan et al., 2011 & Retro & 120 & so & $\mathrm{AL} 120-150 \mathrm{~cm}, \mathrm{BL} 50-80 \mathrm{~cm}$ & Longer limbs was not associated with greater \%EWL. \\
\hline Risstad et al., 2016 & $\mathrm{RCT}$ & 113 & SO & $\mathrm{AL} 150 \mathrm{~cm}, \mathrm{BL} 50 \mathrm{~cm}$ & $\begin{array}{l}\text { Support } \mathrm{CL}>=150 \mathrm{~cm} \text {, to avoid nutricional deficiencies } \\
\text { and diarrhea. }\end{array}$ \\
\hline Nergård et al., 2020 & RCT & 140 & so & $\mathrm{AL} 150 \mathrm{~cm}, \mathrm{BL} 60 \mathrm{~cm}$ & Support $\mathrm{CL}>=150 \mathrm{~cm}$, to avoid diarrhea. \\
\hline Ruiz-Tovar et al., 2019 & $\mathrm{RCT}$ & 506 & NSO & $\mathrm{AL} 150 \mathrm{~cm}, \mathrm{BL} 70 \mathrm{~cm}$ & $\mathrm{BL} 120 \mathrm{~cm}$ was associated with greater ND. \\
\hline Savassi-Rocha et al., 2008 & Prosp & 100 & NSO, SO & $\mathrm{AL} 110 \mathrm{~cm}, \mathrm{BL} \sim 60 \mathrm{~cm}$ & $\begin{array}{l}\text { Support CL } \sim 400-600 \mathrm{~cm} \text {. Suggest measuring JIL to avoid } \\
\text { greater ND. }\end{array}$ \\
\hline Tacchino, 2015 & Prosp & 443 & NSO, SO & NR & Suggest measuring JIL to avoid greater ND. \\
\hline Chen et al., 2019 & Prosp & 377 & NSO, SO & $\mathrm{AL} 150 \mathrm{~cm}, \mathrm{BL} 100 \mathrm{~cm}$ & Support $\mathrm{CL}>400 \mathrm{~cm}$ to avoid protein deficiency. \\
\hline Ghiassi et al., 2018 & Prosp & 96 & NSO, SO & $\mathrm{AL}+\mathrm{CL}>=400-450 \mathrm{~cm}$ & AL $100 \mathrm{~cm}$. Support CL $>150-200 \mathrm{~cm}$, to avoid ND. \\
\hline Nergaard et al., 2014 & RCT & 187 & NSO, SO & $\mathrm{AL} 150 \mathrm{~cm}, \mathrm{BL} 60 \mathrm{~cm}$ & BL $200 \mathrm{~cm}$ was associated with greater ND and diarrhea. \\
\hline Mahawar et al., 2016 & SR & NR & NSO & $\mathrm{AL}+\mathrm{BL} 100-200 \mathrm{~cm}$ & Support $\mathrm{CL}>=100 \mathrm{~cm}$, to avoid ND. \\
\hline Sugerman et al., 1997 & Prosp & 27 & SO & AL $100 \mathrm{~cm}, \mathrm{BL} 200-300 \mathrm{~cm}$ & $\begin{array}{l}\mathrm{CL} 50 \mathrm{~cm} \text { is unacceptable. } \mathrm{CL} 150 \mathrm{~cm} \text { can be used for SO } \\
\text { with comorbidities. }\end{array}$ \\
\hline Gadiot et al., 2020 & RCT & 444 & NSO, SO & $\mathrm{AL} 150 \mathrm{~cm}, \mathrm{BL} 60 \mathrm{~cm}$ & $\mathrm{CL}<100 \mathrm{~cm}$ was associated with greater ND. \\
\hline
\end{tabular}

Abbreviations: \%EWL, excess weight loss; $\mathrm{AL}$, alimentary limb; BL, biliopancreatic limb; $\mathrm{BMI}$, body mass index; $\mathrm{CL}$, common limb; $\mathrm{DM} 2$, type 2 diabetes mellitus; JIL, jejunoileal length; MA, meta-analysis; n, number of patients; ND, nutritional disorders; NR, not revealed; NSO, non-superobese; Prosp, prospective study; RCT, randomized clinical trial; Retro, retrospective study; SO, superobese; SR, systematic review.

\section{Anatomical variation in the length of the small intestine}

In addition to the relationship between the postoperative result, a considerable variation of the small intestine length was found in the studies (Table 2). According to the studies, male individuals had longer average lengths, and no relationship was found between the length of the small intestine and the preoperative BMI. 
Landal \& Cabral.

Table 2: Small intestine length variation found in the analyzed articles.

\begin{tabular}{l|l|l}
\hline Study & Small intestine & Other information \\
\hline Chen et al., 2019 & $490-1320 \mathrm{~cm}$ & - \\
\hline Gadiot et al., 2020 & $355-985 \mathrm{~cm}$ & Longer in men $(p=0,002)$. No relationship was found between length and BMI \\
\hline Gleysteen, 2009 & $302-792 \mathrm{~cm}$ & No relationship was found between length and BMI \\
\hline Kaska et al., 2014 & $325-650 \mathrm{~cm}$ & - \\
\hline Nergaard et al., 2014 & $420-870 \mathrm{~cm}$ & - \\
\hline Savassi-Rocha et al., 2008 & $434-990 \mathrm{~cm}$ & Longer in men $(p<0,005)$. No relationship was found between length and BMI \\
\hline Tacchino, 2015 & $350-1049 \mathrm{~cm}$ & Longer in men $(p<0,0001)$ \\
\hline
\end{tabular}

Abbreviations: BMI, body mass index.

\section{Discussion}

According to the analyzed studies, bariatric surgery of RYGB is a safe and effective technique for treating obesity and associated comorbidities. Although several studies correlate limb length with excess weight loss and nutritional deficiencies in patients undergoing RYGB, the heterogeneity of measures and follow-up still maintains this controversial subject in the literature. A possible limitation is the accuracy of the measurement of the limb lengths, as there may be variations during the laparoscopy technique (Tacchino, 2015). However, despite the limitations, the studies present in this review could guide future studies and strategies in decision-making about RYGB surgery.

Some studies show benefit from \%EWL with more prolonged intestinal bypass in superobese patients $\left(B M I>=50 \mathrm{~kg} / \mathrm{m}^{2}\right)$. In these patients, an $\mathrm{AL}$ close to $150 \mathrm{~cm}$ or $\mathrm{AL}+\mathrm{BL}=200-300 \mathrm{~cm}$ can bring a good \%EWL with minor nutritional deficiencies (Brolin et al., 1992; Ciovica et al., 2008; Gleysteen, 2009; Stefanidis et al., 2011; Gan et al., 2018). However, there is evidence that concludes that the limb length does not influence the postoperative result. In patients with a $B M I<50 \mathrm{~kg} / \mathrm{m}^{2}$, an AL 75-100 cm with BL 50-100 cm (AL + BL = $100-200 \mathrm{~cm}$ ) also let to a proper \%EWL without more significant nutritional deficiencies (Choban \& Flancbaum, 2002; Inabnet et al., 2005; Christou et al., 2006; Sarhan et al., 2011; Valezi et al., 2014; Mahawar et al., 2016; Ramos et al., 2016; Risstad et al., 2016; Ruiz-Tovar et al., 2019; Gadiot et al., 2020; Nergård et al., 2020). In cases of patients with severe comorbidities, like severe DM2 and/ or severe dyslipidemia, probably longer BL could be beneficial aimed comorbidities resolution, and specific evidence supports a BL close to $150 \mathrm{~cm}$ in those patients ( Pinheiro et al., 2008; Kaska et al., 2014; Nora et al., 2017; Homan et al., 2018).

Several studies mention that very short common limb can lead to severe protein malnutrition, higher nutrient deficiency, and diarrhea, especially if $<150 \mathrm{~cm}$. CL ideally longer than $250-400 \mathrm{~cm}$ may decrease the incidence of nutritional disorders, confirming the importance of measuring the intraoperative jejunoileal length and individualizing the surgery due to the wide variation in the small intestine of patients ( Sugerman et al., 1997; Savassi-Rocha et al., 2008; Kaska et al., 2014; Nergaard et al., 2014; Tacchino, 2015; Mahawar et al., 2016; Risstad et al., 2016; Ghiassi et al., 2018; Chen et al., 2019; Ruiz-Tovar et al., 2019; Gadiot et al., 2020; Nergård et al., 2020).

The limb length is essential; however, long-term weight loss is influenced by several variables, mainly by changes in lifestyle and also by the restrictive component of the gastric pouch. Therefore, further studies are needed, essentially long-term controlled and randomized studies, which correlate the length of the three intestinal limbs with the patients' jejunoileal measurement.

In the future, perhaps the routine of the bariatric surgeon will include measuring the intraoperative jejunoileal length, and with this question clarified, they will be able to perform more individualized surgeries that help the patient with significant weight loss, in addition to improving metabolic diseases, and possibly generating a lower rate of nutritional disorders and revisional surgical approaches.

\section{Conclusion}

There is a lack of consensus and varying opinions among experts about the limb lengths in RYGB surgeries. Otherwise, current evidence supports using shorter limb lengths in patients with $\mathrm{BMI}<50 \mathrm{~kg} / \mathrm{m}^{2}$ and longer limbs in patients with severe DM2 and/or dyslipidemia or superobese patients $\left(\mathrm{BMI}>=50 \mathrm{~kg} / \mathrm{m}^{2}\right)$ considering the benefits in \%EWL and comorbidities resolution. Common limb $<150 \mathrm{~cm}$ increases the incidence of nutritional disorders, confirming the importance of measuring the intraoperative jejunoileal length and individualizing the surgery. However, there is high heterogeneity in the studies, highlighting the importance of future randomized trials on this topic. 
Landal \& Cabral.

\section{Funding Sources}

No funding sources

\section{Contributions and conflicts declared by the authors}

Bruno Landal Cavassin conceived the idea, carried out the bibliographic search, wrote the manuscript, and reviewed different versions of it. Carolina Cabral Brandalizze conceived the idea, carried out the bibliographic search, wrote the manuscript, and reviewed different versions of it. The authors declare that they have no conflict of interest when conducting this research.

\section{References}

Ahmed B, King WC, Gourash W, Hinerman A, Belle SH, Pomp A, Pories WJ. \& Courcoulas AP. (2019). Proximal Roux-en-Y gastric bypass: Addressing the myth of limb length. Surgery (United States) $166,445-455$.

Brolin RE, Kenler HA, Gorman JH. \& Cody RP. (1992). Long-limb Gastric Bypass in the Superobese: A Prospective Randomized Study. Annals of Surgery 215, 387-395.

Chen JC, Shen CY, Lee WJ, Tsai PL. \& Lee YC. (2019). Protein deficiency after gastric bypass: The role of common limb length in revision surgery. Surgery for Obesity and Related Diseases 15, 441-446.

Choban PS. \& Flancbaum L. (2002). The effect of Roux limb lengths on outcome after Roux-en-Y gastric bypass: A prospective, randomized clinical trial. Obesity Surgery 12, 540-545.

Christou NV, Look D. \& MacLean LD. (2006). Weight gain after shortand long-limb gastric bypass in patients followed for longer than 10 years. Annals of Surgery 244, 734-740.

Ciovica R, Takata M, Vittinghoff E, Lin F, Posselt AM, Rabl C, Stein HJ. \& Campos GM. (2008). The impact of roux limb length on weight loss after gastric bypass. Obesity Surgery 18, 5-10.

Engin A. (2017). The Definition and Prevalence of Obesity and Metabolic Syndrome. Advances in Experimental Medicine and Biology 960, 1-17.

Gadiot RPM, Leeman M, Biter LU, Dunkelgrun M, Apers JA, van't Hof G, Feskens PB. \& Mannaerts GH. (2020). Does the Length of the Common Channel as Part of the Total Alimentary Tract Matter? One Year Results from the Multicenter Dutch Common Channel Trial (DUCATI) Comparing Standard Versus Distal Roux-en-Y Gastric Bypass with Similar Biliopancreatic Bowel Limb. Obesity Surgery 30, 4732-4740.
Gan J, Wang Y. \& Zhou X. (2018). Whether a Short or Long Alimentary Limb Influences Weight Loss in Gastric Bypass: a Systematic Review and Meta-Analysis. Obesity Surgery 28, 3701-3710.

Ghiassi S, Higa K, Chang S, Ma P, Lloyd A, Boone K. \& DeMaria EJ. (2018). Conversion of standard Roux-en-Y gastric bypass to distal bypass for weight loss failure and metabolic syndrome: 3-year follow-up and evolution of technique to reduce nutritional complications. Surgery for Obesity and Related Diseases 14, 554-561.

Gleysteen JJ. (2009). Five-year outcome with gastric bypass: Roux limb length makes a difference. Surgery for Obesity and Related Diseases 5, 242-247.

Homan J, Boerboom A, Aarts E, Dogan K, van Laarhoven C, Janssen I. \& Berends F. (2018). A Longer Biliopancreatic Limb in Roux-en-Y Gastric Bypass Improves Weight Loss in the First Years After Surgery: Results of a Randomized Controlled Trial. Obesity Surgery 28, 3744-3755.

Inabnet WB, Quinn T, Gagner M, Urban M. \& Pomp A. (2005). Laparoscopic Roux-en-Y Gastric Bypass in Patients with $\mathrm{BMI}<50$ : A Prospective Randomized Trial Comparing Short and Long Limb Lengths. Obesity Surgery 15, 51-57.

Kaska Ł, Kobiela J, Proczko M, Stefaniak T \& Śledziński Z. (2014). Does the length of the biliary limb influence medium-term laboratory remission of type 2 diabetes mellitus after Roux-en-Y gastric bypass in morbidly obese patients? Wideochirurgia I Inne Techniki Maloinwazyjne 9, 31-39.

Mahawar KK, Kumar P, Parmar C, Graham Y, Carr WRJ, Jennings N, Schroeder N, Balupuri S \& Small PK. (2016). Small Bowel Limb Lengths and Roux-en-Y Gastric Bypass: a Systematic Review. Obesity Surgery 26, 660-671.

Nergaard BJ, Leifsson BG, Hedenbro J \& Gislason H. (2014). Gastric Bypass with Long Alimentary Limb or Long Pancreato-Biliary LimbLong-Term Results on Weight Loss, Resolution of Co-morbidities and Metabolic Parameters. Obesity Surgery 24, 1595-1602.

Nergård BJ, Leifson BG, Gislason H \& Hedenbro JL. (2020). Effect of different limb lengths on quality of life, eating patterns and gastrointestinal symptoms after Roux-en $-Y$ gastric bypass in superobese patients: randomized study. BJS Open. 4, 1109-1116.

Nora M, Morais T, Almeida R, Guimarães M \& Monteiro MP. (2017). Should Roux-en-Y gastric bypass biliopancreatic limb length be tailored to achieve improved diabetes outcomes? Medicine (United States) 96, e8859. 
Landal \& Cabral.

Pinheiro JS, Schiavon CA, Pereira PB, Correa JL, Noujaim P. \& Cohen R. (2008). Long-long limb Roux-en-Y gastric bypass is more efficacious in treatment of type 2 diabetes and lipid disorders in super-obese patients. Surgery for Obesity and Related Diseases 4, 521-525.

Ramos A, Kow L, Brown W, Welbourn R, Dixon J, Kinsman R. \& Walton P. (2019). Fifth IFSO Global Registry Report 2019. Accedido https:// www.ifso.com/pdf/5th-ifso-global-registry-report-september-2019. pdf el 03 de febrero de 2020.

Ramos RJ, Mottin CC, Alves LB, Benzano D. \& Padoin AV. (2016). Efeito Da Dimensão Das Derivações Intestinais Em Obesos Com Síndrome Metabólica Submetidos Ao Bypass Gástrico. Arq Bras Cir Dig. 29, 15-19.

Risstad H, Svanevik M, Kristinsson JA, Hjelmesaeth J, Aasheim ET, Hofso D, Sovik TT, Karlsen TI, Fagerland MW, Sanbdu R. \& Mala T. (2016). Standard vs distal roux-en-Y gastric bypass in patients with body mass index 50 to 60 a double-blind, randomized clinical trial. JAMA Surgery 151, 1146-1155.

Ruiz-Tovar J, Vorwald P, Gonzalez-Ramirez G, Posada M, Salcedo G, Llavero C. \& Garcia-Olmo D. (2019). Impact of Biliopancreatic Limb Length $(70 \mathrm{~cm}$ vs $120 \mathrm{~cm}$ ), with Constant $150 \mathrm{~cm}$ Alimentary Limb, on Long-Term Weight Loss, Remission of Comorbidities and Supplementation Needs After Roux-En-Y Gastric Bypass: a Prospective Randomized Clinical Trial. Obesity Surgery 29, 2367-2372.
Sampaio-Neto J, Branco-Filho AJ, Nassif LS, Nassif AT, Masi FDJ de \& Gasperin G. (2016). PROPOSAL OF A REVISIONAL SURGERY TO TREAT SEVERE NUTRITIONAL DEFICIENCY POST-GASTRIC BYPASS. $A B C D$ Arq Bras Cir Dig 29, 98-101.

Sarhan M, Choi JJ, Al Sawwaf M, Murtaza G, Getty JLZ \& Ahmed L. (2011). Is weight loss better sustained with long-limb gastric bypass in the super-obese? Obesity Surgery 21, 1337-1343.

Savassi-Rocha AL, Diniz MTC, Savassi-Rocha PR, Ferreira JT, Sanches SRA, Diniz MFHS, Barros HG. \& Fonseca IK. (2008). Influence of jejunoileal and common limb length on weight loss following Roux-en-Y gastric bypass. Obesity Surgery 18, 1364-1368.

Stefanidis D, Kuwada TS. \& Gersin KS. (2011). The importance of the length of the limbs for gastric bypass patients-an evidence-based review. Obesity Surgery 21, 119-124.

Sugerman HJ, Kellum JM. \& DeMaria EJ. (1997). Conversion of Proximal to Distal Gastric Bypass for Failed Gastric Bypass for Superobesity. Journal of Gastrointestinal Surgery 1, 517-525.

Tacchino RM. (2015). Bowel length: measurement, predictors, and impact on bariatric and metabolic surgery. Surgery for Obesity and Related Diseases 11, 328-334.

Valezi AC, Marson AC, Merguizo RA \& Costa FL. (2014). Roux-en-Y gastric bypass: limb length and weight loss. ABCD Arq Bras Cir Dig. 27, 56-58. 